\title{
Journal of Agronomy and Agricultural Aspects
}

Research Article

Novikov YI, etal. J Agr Agri Aspect (2016): JAAA-101.

\section{Formation of the Grain Market and its Competitive Environment}

\author{
Yuri Ivanovich Novikov*
}

Federal State Educational Institution of Higher Education, Omsk State Agrarian University, Omsk, Russia.

"Corresponding author: Yuri Ivanovich Novikov, Federal State Educational Institution of Higher Education, Candidate of Economic Sciences, Associate Professor, Omsk State Agrarian University n. a. P.A. Stolypin, Omsk, Russia. E-Mail: ui.novikov@, omgau.org.

Citation: Navikov Yi (2016) Formation of the grain market and its competitive environment. J Agr Agri Aspect 2016: JAAA-101.

Received Date: 02 November, 2016; Accepted Date: 21 November, 2016; Published Date: 28 November, 2016

\section{Abstract:}

The article reveals the peculiarities of the domestic grain market and its competitive environment, the characteristic of the main subjects of the market and the degree of their impact on market relations, taking into account the specificity of natural and economic conditions, reflected the role of the public purchasing interventions and their impact on the grain market.

Keywords: Grain Market; The Competitive Environment; The Purchasing Intervention; Market Infrastructure; Demand; Supply; Market Actors; Producers; Consumers; Grain Yield

\section{Article:}

The basis of market relations is the mutual interest between producers and consumers, contributing to increase production volumes on the one hand and encourage rational use of the products on the other. In such circumstances, formed as a rule all the food markets, including the market of grain.

According to the structure of the markets are divided according to the following criteria: economic purpose objects of market relations (markets of goods and services, the means of production, scientific and technological development, securities, labor, etc.); by commodity groups (capital goods, consumer goods, foodstuffs, raw materials, etc.).

Markets are also divided by industry production - sources of commodity resources (agricultural - agricultural products, machinery and equipment, materials, energy and other).

For agricultural research, and a number of other markets, products are produced over a wide area and is consumed universally important territorial criterion for their classification. According to him allocate markets (intra-regional, inter-regional, national, inter-republican, international (global).

In terms of economic freedom, market actors, through the mechanism of supply and demand interaction solve three basic questions of functioning of economic relations: what to produce, by what means, and for some consumers.

Under the grain market, we understand the functioning of grain production, which in addition to the exchange transactions includes all commodity-money relations governing the production, distribution and consumption of grains forming the connection between the subjects of the grain market.

The main features of the developed market are solvent and meet demand, the association of producers, intermediaries and suppliers, non-interference of state bodies in the economic activities of individual market participants.

The beginning of the formation of the legal basis Russian grain market with its inherent competitive environment was initiated cancellation, which existed in the period of planned management of the national economy, the state monopoly on grain procurement. In 1991, after the abolition of the agricultural industry, State Logistics Committee and the State Planning Committee of the Russian Federation of grain in the country gradually began to go out of state control. Important for the formation of the grain market of Russia was the adoption of the law of the Russian Federation "On Grain" (1993), the Russian President's decree "On liberalization of the grain market of Russia" (1993) and some other legal acts.

Since 1994, the grain market covered almost the entire territory of Russia, and commercial firms began selling all kinds of grain. In agricultural markets, including grain producers and the market in a significant number of cases independently implement the resulting products. The most common reason for this is the desire of the agricultural enterprises and farms to avoid the direct and opportunity costs of material related to the payment of such services, as well as the loss on the difference in selling prices.

In the 1990 s, the cereal market was formed in an unfavorable economic situation caused by the liberalization of prices for 
means of production and services, as well as foreign trade activity, a sharp reduction in capital investments, frustration and financial and credit system, reduction of solvent demand of the population.

This process was accompanied by disastrous consequences in the form of a continuous decline in grain production and the deterioration of its quality. Created in the pre-reform period, the productive capacity of grain production are gradually lost, decreasing the basic indicators of the grain industry.

In modern conditions the grain market participants are its producers, processing companies, small and large Russian grain company. As the grain trade activities of business firms operating in the grain market are changing. Originally of grain in Russia had an obvious, speculative. The grain bought by cheap and resold at a much higher price.

As the market development of grain difference between the price of purchase and sale decreased for the success of the companies in the market there is a need to have more funds. As a result, small firms were replaced by larger in a competitive environment.

Since operations resale grain became less profitable, private firms have started to gradually move towards participation in its processing, as well as expand the scope of services provided.

An important condition for the development and functioning of a free grain market is a constant and growing demand in consumption at him. Under the demand to understand the need for grain for food purposes, seed and fodder grain, for further processing, as well as to create a reserve fund and strategic reserves.

There are aggregate demand, quantification of total grain demand in the world (country, region) and the pent-up demand, the negative difference between the supply of grain and aggregate demand.

\section{Demand for grain is characterized by its instability. It is influenced by factors such as:}

Demographics: the size and growth of population, per capita consumption;

Policy: sanctions, humanitarian aid, embargo, food security;

Economic: the efficiency of production per 1 ha. the cultivated area; the level of prices on the market; profitability, etc.

Technological: seeding rate per 1 ha .; grain consumption rates in the processing industry for the production of the final product unit; flow rate of feed grain per unit of livestock production.

There is an active process of formation of the competitive environment in the grain market. Features of natural and economic conditions of the country determine the specificity of the domestic grain market, which is dominated by large land users, with a large amount of grain produced and diversified economy with the development of crop and animal husbandry.

The main, stable grain sales channels in the country are state intervention Bole occupying 60\%. The increase and expansion of distribution channels in the grain market and its products is the main condition for the formation of market relations and development of the wound as a whole.

Major grain-processing enterprises, and points (elevators) is carried out purchases of grain to create large consignments, conducted primary part time and processing of grain into flour, cereals, animal feed, etc.

Grain-points have their own base for long-term storage of grain, have laboratories for research of grain products, feature items and equipment for acceptance and shipment of consignments. They are the main operators of the grain market in the country.

Agricultural company producing grain is free competition market. A feature of this type of market from the other types is the presence of a large number of similar products manufacturers and sellers of a large number of consumers.

In this case, grain producers are forced to accept the market price, and not in a position to dictate its own terms. They do not have their own pricing policy and cannot have a significant impact on the market price.

An integral part of the implementation of the functioning of the market mechanism are commodity exchanges, which serve to ensure communication between buyers and sellers during which prices are formed and executed purchase and sale.

In today's market conditions, for grain producers, the main task, along with the production of high quality products, and its implementation is the increase in consumer demand.

In recent years, significantly reduced purchases of the federal and regional funds grains of hard and strong wheat, although in some years they produced in the country is enough for food purposes. However, due to the imperfect economic mechanism and shortcomings in the functioning of the grain market of the need for it is not satisfied, as part of the gross collection of high-quality wheat is consumed even for fodder.

With an increase in material and energy costs especially grain production exceeds the profitability of most of the other branches of agriculture. The ratio of the price of wheat, flour and bread is not in favor of grain producers. A disproportionate part of the final price goes to intermediaries and retail trade. But we should not assume that this price ratio is characteristic only of Russian grain market. At the EU grain market price is only $5-7 \%$ of the retail price of bread. 
In this regard, to improve the conditions for the implementation of the grain must be all-round development of cooperation and agro-industrial integration, bringing together on mutually beneficial economic conditions, grain production, grain storage, reprocessing and subsequent implementation of the final product.

Based on the current situation in the grain market, we can assume that in the short term large commodity grain producing farms are able to organize cereal regional associations (companies) unite on the basis of co-operative production, storage, transportation and processing of grain. This, of course, one should not exclude the possibility of each grain producers to find their own market, including by direct contacts.

The Civil Code and other regulations have created the necessary legal framework regulating the circulation of goods, works and and cash flows in the modern economy of Russia. The legislation established that agricultural products, raw materials and food products are the property of producers and sold by them at their discretion, based on the economic benefits.

Complete freedom of producers as well as other owners of grain, in the selection of its distribution channels, the conditions for the formation of market prices and ensuring the free movement of goods according to the contract is the most important feature of the grain markets of all countries.

Average grain market functioning and development is possible only if the creation of an integrated system of legal, economic, organizational and administrative measures protecting all participants of the administrative arbitrariness of local authorities.
The prospects of the grain market of Russia is characterized by its high export potential, based on the available resources the export of grain and the demand for it in the near and far abroad. For the development of Russia's export potential as a long-term priority needs state support. It must be through the subsidization of transportation costs, removal of customs duties and refund of value added tax and other measures.

With the development of the grain market and to enhance its openness in connection with the entry of most countries in the WTO, the increasing importance of protecting domestic producers of grain from the competition of imported products.

\section{References}

1. Алтухов А.И., Васютин А.С. ЗерноРоссии. - М.:Экондс-К, 2002. -432 с.

2. БезопасностьРоссии. Правовые, социально-экономические и научнотехническиеаспекты. Продовольственнаябезопасность.Разделы 1 и 2 / А.В. Гордеев, О.А. Масленникова, Д.Ф. Вермель, А.И. Алтухов и др. М.: МГФ «Знание». Раздел 1, 2000. - 544 с. Раздел 2, 2001. - 480 с.

3. Рекомендациипорегулированиюпроизводства и рынказерна, сахара, говядины, свинины, мясаптицы, молока /Алтухов А.И., Силаева Л.П., Кундиус В.А., Магомедов А.Н., Осипов А.Н., Куропаткин А.Н., Жидков С.А., Винничек Л.Б., Гончарова Н.З., Новиков Ю.И. и др. Научноеиздание / Пермь, 2006. 